(and expensive) trials have thoroughly field tested Keys's experimental conclusion that changes in plasma cholesterol concentration reflect changes in dietary intake of saturated fatty acids. ${ }^{+}$In the American multiple risk factor intervention trial, a randomised prospective controlled trial, 6428 middle aged men were persuaded to stick to a diet low in saturated fatty acid, low in cholesterol, and high in fibre (it was also low in salt for people with hypertension and low in energy for obese people). ${ }^{5}$ The special intervention regimen, much as proposed by the Committee on Medical Aspects of Food Policy and the World Health Organisation $^{7}$ for coronary prevention, was aggressively pursued. There was no significant effect on mortality from coronary heart disease or any clinically important effect on plasma cholesterol concentration over the seven years of the study.

These results were confirmed by the WHO European Collaborative Group's prospective controlled study, which randomised 80 factories across Europe (over 60000 men aged 40 to 59) to intervention or control status. ${ }^{8}$ The intervention was similar to that proposed by O'Connor's group. The trial lasted for five years, and the effects of intervention on both mortality and plasma cholesterol concentration were even smaller and less clinically relevant than those in the American trial.

Before campaigners like the Coronary Prevention Group - they are proliferating exponentially - try to rouse an uncritical populace to a state of dietary hysteria and demand action from the government of the day they should do their homework and review the evidence in support of a useful outcome from their activities. Currently the evidence is much more strongly in favour of walking briskly for half an hour each day and eschewing all dietary advice save that which recommends not eating more than is needed to stay fit and slim. ${ }^{9}$

London W1M 7AD

ALEXANDER MACNAIR

$1 O^{\prime}$ Connor $M$. Europe and nutrition: prospects for public health. BMF 1992;304:178-80. (18 January:)

2 Keys A. Seven countries: a multivariate analysis of death and coronary heart disease. Cambridge, Massachusetts: Harvard University Press, 1980

3 James W'PT. Healthy nutrition: preventing nutrition-related diseases in Europe. Copenhagen: WHO Regional Office for Europe, 1988.

4 Keys A, Anderson JT, Grande F. Prediction of serum-cholesterol responses of man to changes in fats in the diet. Lancet 1957:ii:959-66.

5 Multiple Risk Factor Intervention Trial Research Group. Multiple risk factor intervention trial: risk factor changes and mortality results. FAMA 1982;248:1465-77.

6 Committee on Medical Aspects of Food Policy. Diet and cardiovascular disease. London: HMSO, 1984. (Report on health and social subjects No 28 .)

7 World Health Organisation Study Group on Diet, Nutrition, and Prevention of Noncommunicable Diseases. Diet, nutrition and the prevention of chronic diseases. WHO Tech Rep Ser 1990: No 797.

8 World Health Organisation European Collaborative Group. Multifactorial trial in the prevention of coronary heart disease. 3. Incidence and mortality results. Eur Heart F 1983;4:141-7.

9 Koplan JP, Caspersen CJ, Powell KE. Physical activity, physical fitness and health: time to act. FAMA 1989;262:2437.

\section{Who speaks for whom in Europe?}

SIR, - In our view Tessa Richards gives a negative picture that is not quite accurate of the efforts of European organisations to represent European doctors in Brussels and wherever else decisions are made of relevance for the medical profession.

Richards's picture of the Standing Committee of Doctors of the EC does not correspond to our own experience. Innuendo about "generous entertainment" misses the point that, in fact, a meeting of the committee consists of long days of hard work in committee rooms, corridors, and reception lines to attempt to determine the united view of the profession in the 12 countries of the European Community on matters important to the profession. We do not agree that what took place last October in Madrid was "too little too late." The decisions made there for the standing committee's future work were vital ones that will lead to even stronger representation of the profession in Europe, as evidenced by the effective start made by the new Portuguese presidency.

We do not agree that the standing committee has been ineffective in getting its views across to the decision makers. Certainly the task is difficult, but the committee and the other groups have succeeded in the past: with the doctors' directives in 1975; the general practice directives in 1986; the advanced informatics in medicine programme; the numerous major cooperations such as the consensus conference on cancer training in general practice organised by the European Union of General Practitioners and the European Commission in 1991; and the many, continuing details the profession has put forward successfully regarding specific issues under consideration in Brusselsfor example, the draft directive on liability for services; the genome working group; and ethical, social, and legal considerations.

With regard to Richards's comments on the European Union of General Practitioners, introducing a three year minimum training for general practice will naturally be difficult, but it would be pitiful if an organisation such as the union did not set and follow political objectives in the long term. Our British colleagues in the union have themselves contributed enormously to the effort to raise standards of training for general practice, not only in Great Britain but everywhere in Europestandards that in the past seemed perhaps an impossible uphill run.

The British delegation on the Standing Committee of Doctors of the EC also contributes greatly, most recently in the work of the task force that established a permanent secretariat for the committee in Brussels. We believe that the work of these organisations has proved to be of real value for the profession and will continue to do so. The British delegation has taken a leading and positive role and we salute that effort.

OLE ASBJØRN JENSEN THOMAS E KENNEDY

European Union of General Practitioner

DK-2100 Copenhagen $\varnothing$

Denmark

1 Richards T. Who speaks for whom? BMJ 1992;304:103-6. (11 January.

\section{One car down}

SIR, - I support R S Bhopal for setting an example by using public transport ${ }^{1}$ and applying some of the lessons brought out in Fiona Godlee's article on transport and public health issues. ${ }^{2}$ As a pathologist working in an area where the annual number of deaths in road accidents has increased, whereas the national average has decreased, I too often see the disastrous results of road traffic accidents. When people with credibility in the community, such as hospital doctors and scientists, set an example by walking or using cycles or public transport this should substantiate concern about the fairly obvious detrimental effects of overusing the car.

Doctors were the first group to stop smoking, and many years later the battle against smoking, if not won, is at least not lost. Lord Gort, the governor of Malta during the blitz, set an example to the rest of the population to save fuel by walking to work. If sufficient numbers of people transferred from using private cars to other forms of transport this should ultimately have an effect on those making decisions about transport, such as city planners and politicians

Perhaps the BMA should set an example: now that BMA House is smoke free perhaps its courtyard should be made car free.

IVAN H GIBSON

Area Department of Histopathology and Cytology,

Dumfries and Galloway Royal Infirmary,

Dumfries DG1 4AP

1 Bhopal RS. One car down. BMf 1992;304:451-2. (15 February.)

2 Godlee F. Transport: a public health issue. BMF 1992;304: 48-50. (4 January.)

SIR, - Congratulations to R S Bhopal for giving up his car and for his eloquent exposition of his reasons for doing so. ${ }^{\prime}$ It is appropriate that a professor of public health should set an example and draw attention to the scale of the damage to health and the environment wrought by the car. I agree that all health professionals have a responsibility to act on this issue.

As part of a two car, two general practitioner family I, however, have not been able to act on my convictions. In my practice we have considered having one practice car for the on call doctor, with the other doctors doing nearby house calls on foot or bicycle. In reality "nearby" is not near enough, given time constraints, and some patients expect the doctor of their choice to visit them. I believe that we may look back on this phase of general practice, when at any weekday lunchtime roughly 34 general practitioners are driving over the same large area of west Newcastle to visit perhaps 150 people, as a period of inefficiency and extravagance.

Urban general practitioners generally operate from bases sited by historical accident and serve populations scattered over wide areas, overlapping with several other doctors' territories. There is also the tradition of patient choice, and patients can live anywhere if the doctor can be persuaded to visit them. Until environmental concerns take priority over these traditions - that is, until general practice is geographically based, which does not exclude a degree of patient choice-general practitioners will not be able to follow Bhopal's example.

GAIL YOUNG

Newcastle upon Tyne NE4 9BB

1 Bhopal RS. One car down. BMf 1992;304:451-2. (15 February.)

SIR, - R S Bhopal is courageous to take to his feet and abjure his car.' $\mathrm{He}$ is right to rank this forebearance above not smoking and reducing fat intake, but I was disappointed that he didn't mention the advantage of the bicycle as an alternative to the car. Two thirds of journeys to work and well over half of trips made for social and entertainment reasons are under $8 \mathrm{~km}$ longideal cycling distance. A 10 -fold increase in the use of cycles in the United Kingdom would save up to $0.75 \times 10^{6}$ tonnes of carbon monoxide, 100000 tonnes of nitrogen oxide, and $16 \times 10^{\circ}$ tonnes of carbon dioxide from being emitted into the atmosphere each year. ${ }^{2}$ And this is not to mention the health benefits of cycling: regular cyclists typically enjoy a fitness level equivalent to being 10 years younger.

I cannot better Williams's words about the bicyclist: He moves easily, intelligently, and cleanly about his city or countryside with an energy expenditure equivalent to over 1400 miles to the gallon. . . . He combines a relatively simple machine with a propulsion unit of quite incredible functional elegance, and in the league of all movers - caterpillars, comets, or Cadillacs-there is nothing to touch him. ${ }^{4}$

TONY WATERSTON

Newcastle General Hospital,

Newcastle upon Tyne NE4 6BE

1 Bhopal RS. One car down. BM7 1992;304:451-2. (15 February.) Rowell A, Fergusson M. Bikes not fumes. Godalming: Cyclists' Touring Club, 1991

3 Sharp I. On your bike. London: National Forum for Coronary Heart Disease Prevention, 1990.

4 Williams R. De sanitate urbanorum. BMF 1979;ii:1617-21. 